\title{
PHENOLOGY OF Copernicia alba IN FLOODED AND NOT FLOODED ENVIRONMENTS
}

\author{
${ }^{1}$ Maicon Marinho Vieira Araujo, ${ }^{2}$ Francisco Almeida Lobo \\ 1'Universidade de Cuiabá - Departamento de Agronomia - Cuiabá - MT - Brazil maiconmarinho@ outlook.com \\ 2Universidade Federal do Mato Grosso - MT - Brazil - f_a_lobo@ufmt.br
}

Received for publication on: 19/07/2019 - Accepted for publication on: 24/01/2020

\begin{abstract}
Resumo
Fenologia de Copernicia alba em ambiente alagado e não alagado. Objetivou-se descrever os padrões fenológicos reprodutivos e vegetativos de indivíduos de Copernicia alba, popularmente conhecida como carandá, presentes em ambiente alagado e não alagado e testar a relação entre as fenofases vegetativas e reprodutivas e a estacionalidade climática. Os aspectos fenológicos da carandá foram obtidos através da observação quinzenal de 22 indivíduos de duas áreas do pantanal mato-grossense, entre agosto de 2015 e agosto de 2017. A população de carandá apresentou comportamento perenifólio, com floração durante a estação seca e maior intensidade de folhas no período de transição entre o período chuvoso. O brotamento, apesar de contínuo, foi intenso no período chuvoso e o padrão de deciduidade foliar apresenta interferência direta da ausência de chuvas no período seco. A incidência de botões florais ocorreu no período seco e a floração entre o período seco e o chuvoso. O período de frutificação aconteceu no período chuvoso, indicando elevado sincronismo das fenofases.

Palavras-chave: Carandá, floração, frutificação, fenofases.
\end{abstract}

\begin{abstract}
The objective of this study is to describe the reproductive and vegetative phenological patterns of individuals of Copernicia alba, popularly known as "carandá", present in a flooded and non-flooded environment and to test the relations between vegetative and reproductive phenophasesand climatic seasonality. The phenological aspects of the carandá were obtained through a biweekly observation of 22 individuals from two areas of the Pantanal of Mato Grosso between August 2015 and August 2017. The carandá population presented a perennial behavior, flowering during the dry season and a greater leaf intensity in the transition period to the rainy season. Budding, although continuous, was intense in the rainy season, and the leaf deciduous pattern had a direct interference from the absence of rainfalls in the dry period. The incidence of floral buds occurred in the dry period, and the flowering occurred between the dry and rainy periods. The fruiting period occurred in the rainy season, indicating a high synchronism of phenophases.

Keywords: Carandá, flowering, fructification, phenophases.
\end{abstract}

\section{INTRODUCTION}

The Mato Grosso Pantanal is composed by the intersection of four major phytoecological regions, which are regionally known as Deciduous Forest, Semi-deciduous Forest, Cerrado and Chaco. In addition to these four regions, in several portions of the Pantanal there are floristic contacts among the Phytoecological Regions. Although this biome excels in the world conservation scenario because of its high species richness and high rate of vegetal endemism, the Pantanal can be considered a biome threatened by the intense and progressive decharacterization caused by anthropic actions (BELO et al., 2013).

An important endemic species in this biome is the Copernicia alba (Morong ex Morong \& Britton), popularly known as "carandá", belonging to the family Arecaceae. The estimated carandá area in the Pantanal vegetation is $2.3 \%$, the second most representative monotypic formation. The carandá is also found in phytophysiognomies known as mixed forests, where semi-deciduous forest species are found associated with balloon vine (Tabebuia aurea (Manso) B. and H. (FAVA; ALBUQUERQUE, 2011).

Due to its representativeness, studies aiming to understand and produce knowledge on the behavior of this species can be a basis for strategies of conservation and restoration of this biome. In this case, the study of phenology represents a good tool for understanding the factors that influence the reproduction and survival of plant species, contributing to the understanding of the dynamics and structuring of plant communities (MORELLATO et al., 1992).

This is because plants present phenological strategies related to the environmental characteristics of their habitats, their habits, reproductive biology and modes of dispersion (CONCEIÇÃO et al., 2006). The interaction between the phenology of a particular plant species and the seasonal variation in climate is one of the most important determinants of its distribution (CHUINE; BEAUBIEN, 2001). Thus, it is expected that endemic species present phenological responses adapted to the peculiarities of the habitat in which they occur.

FLORESTA, Curitiba, PR, v. 51, n. 1, p. 220-229, jan/mar 2021. 
In addition, understanding the reproductive cycles of plants is of fundamental importance for the conservation and management of native and endangered species. However, phenological studies on plants of the Pantanal biome are scarce, especially in endemic species, such as the carandá (DUTRA et al., 2009; MIOLA et al., 2011).

The objective of this work is to describe the reproductive and vegetative phenological patterns of individuals of Copernicia alba occurring in flooded and not flooded environments of the Pantanal of Mato Grosso, and to test the relationship between their phenophases and climatic seasonality.

\section{MATERIALS AND METHODS}

Study areas

This study was conducted with 12 individuals located in the urban region of Cuiabá at coordinates $15^{\circ} 36^{\prime} 29$ "S and 56 45'16" W and elevation of $140 \mathrm{~m}$, located in Santo Antônio do Leverger - MT, distant 33 km from Cuiabá - MT. Another 10 individuals located in the Jubran Natural Heritage Private Reserve at coordinates $16^{\circ} 53^{\prime} 23.3$ "S and $57^{\circ} 24^{\prime} 22.2^{\prime \prime} \mathrm{W}$ and $104 \mathrm{~m}$ elevation, located in the Municipality of Cáceres - MT, distant $234 \mathrm{~m}$ from Cuiaba - MT. The study comprised the months of August 2016 to August 2018.

The climate of the regions is Aw, according to the Köppen classification, that is, semi-humid tropical, with average temperatures of $24-26^{\circ} \mathrm{C}$, four to five dry months and two well defined seasons: a dry (autumnwinter) and a rainy (spring-summer) season, with an annual rainfall index of 1,250-1,500 mm.

The soils of these sites are typical Dystrophic Petric Plinthosol (VALENTINI et al., 2013). Samples of the soils from Cuiabá and Cáceres were collected at a depth of 0-15 cm and present, respectively, the following characteristics: pH: 5.3 and 5.5; organic matter: $19 \%$ and 33\%; sand: $60 \%$ and 68\%; silt: $22 \%$ and 16\%; and clay: 18 and $16 \%$.

Phenological data

For the phenological monitoring of Copernicia alba, the selected individuals were marked and georeferenced. Specimens of these trees were deposited in the central herbarium of the Federal University of Mato Grosso under the accession number: 44135. From September 2016 to June 2018, biweekly evaluations were conducted at the study site to monitor vegetative phenophases. In some cases, the sacking deposited under the projection of the canopy where floral buds, new aborted fruits, green fruits and ripe fruits were observed, were only examined for conformation of the current phenophases.

The percentage of occurrence of the following phenophases was recorded (KOPTUR et al., 1988): (i) budding: period of the occurrence of leaf buds up to the expansion of new leaves; (ii) leaf fall; (iii) flowering: divided into periods with buds and open flowers; and (iv) fruiting, divided in periods with unripe fruits and ripe fruits. Observations of the phenophases were performed in the dry and rainy periods. In all data collections, we observed the reproductive and vegetative aspects of each species, noting all the data and obtaining the photographic records for possible comparisons of each phenophase.

Data analysis

The data of both places were analyzed separately and comparatively, according to the following indexes:

(1) Activity index is the percentage of individuals in a given phenophase. For a given moment, the presence (1) or absence (0) of individuals in a phenophase is quantified in relation to the total number $(\mathrm{N})$ of individuals sampled. This index, therefore, allows evaluating the synchrony of the individuals of a population. The greater the percentage of individuals in the phenophase, the more synchronized they are (FOURNIER, 1974, SOUZA et al., 2014).

(2) Fournier Intensity or Fournier Index (FORNIER, 1974), which provides the abundance data of the phenophase at an evaluated moment. This index is determined by individual evaluations in the sample, assigning a score (E) to each individual according to the following categorization: 0 - no phenomena observed, 1 - there is the presence of the phenomenon observed with a magnitude from 1 to $25 \%, 2$ - there is the presence of the phenomenon observed with a magnitude of 26 to $50 \%, 3$ - there is presence of the phenomenon observed with a magnitude from 51 to $75 \%$; and 4 - there is presence of the observed phenomenon with a magnitude from 76 to $100 \%$. The calculation was performed by Equation (1) (MARCHIORETTO et al., 2007):

$$
\% \text { Fournier }=\frac{\sum \text { Fournier }}{4 N} \times 100
$$
individuals

Where, $\Sigma$ Fournier $=$ sum of Fournier categories for each individual, and $\mathrm{N}=$ number of sample

In order to analyze how much each phenophase was expressed in a period, that is to say, the amplitude of time in months of each vegetative or reproductive event, we used the methodology proposed by Newstrom et al.

FLORESTA, Curitiba, PR, v. 51, n. 1, p. 220-229, jan/mar 2021. 
(1994). It recognizes three different classes: a short one, in which the event lasts up to one month; an intermediate one, in which the phenophase extends from two to five months; and a long one, in which the phenophase extends for six months or more.

The relations between the occurrence of each phenophase and the climatic variables (air temperature, rainfall, relative humidity, wind speed and radiation) were tested using Spearman correlation and the climatic data of the four fortnights prior to the phenological event (ROCHA et al., 2015). Deviations from the normality of phenological data were confirmed by the Kolmogorov-Smirnov test for use of Spearman non-parametric correlation.

Weather data

Climatic data of rainfall $(\mathrm{mm})$ and average temperature $\left({ }^{\circ} \mathrm{C}\right)$, provided by the National Institute of Meteorology (INMET), were obtained from conventional stations located in the municipalities of Cuiabá and Cáceres (Figures 1).

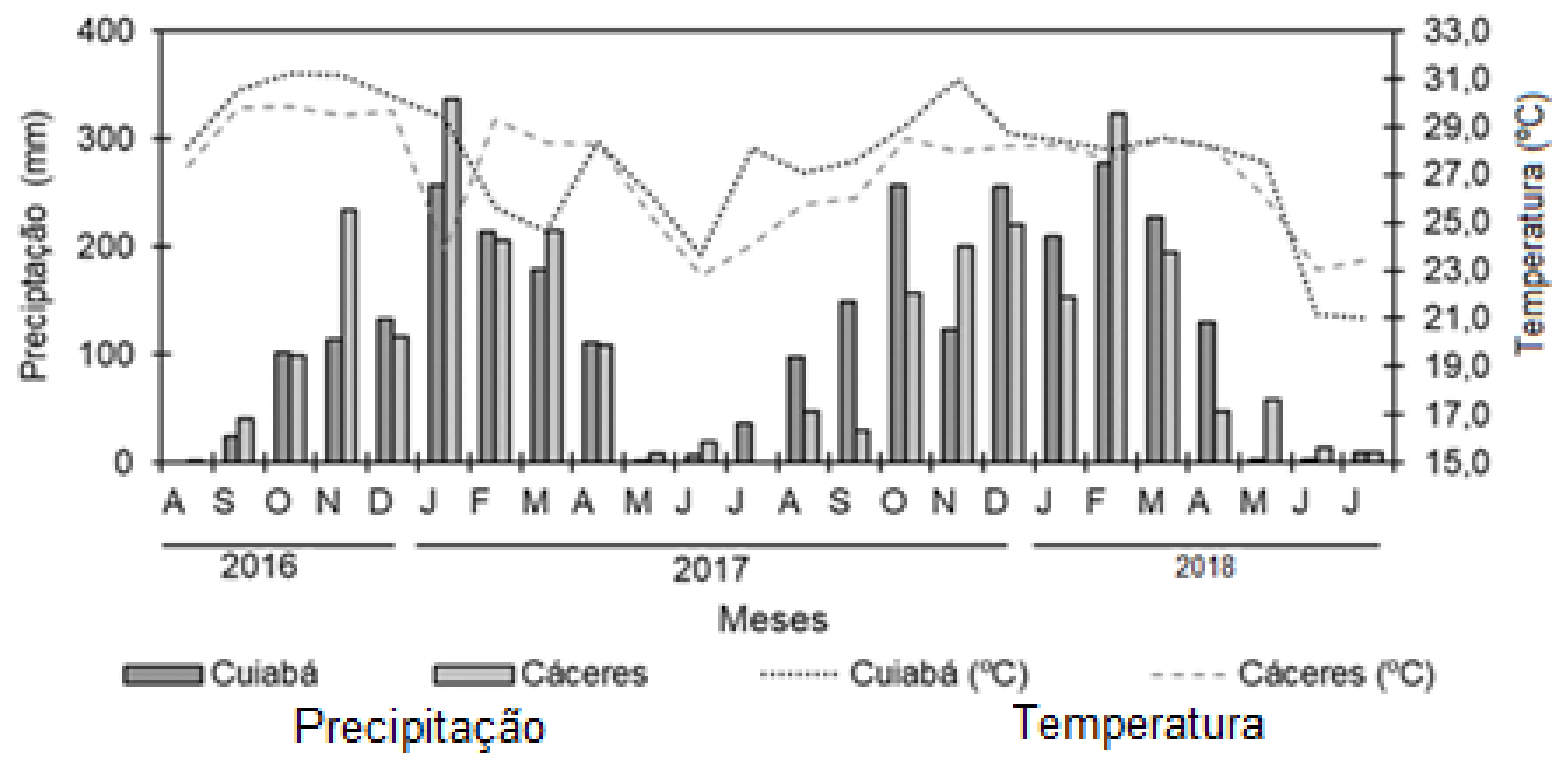

Figura 1. Precipitação (mm) e temperatura média $\left({ }^{\circ} \mathrm{C}\right)$, ao longo dos meses de avaliação, das cidades de Cuiabá/MT e Cáceres/MT.

Figure 1. Rainfall $(\mathrm{mm})$ and average temperature $\left({ }^{\circ} \mathrm{C}\right)$ over the evaluation months of the cities of Cuiabá/MT and Cáceres/MT.

\section{RESULTS}

The rainfall distribution presented two distinct periods for the regions under study. There was a rainy period that extended from October to April, concentrating the highest rainfall rates, which on average equals to $91 \%$ of the rains, followed by a period of drought from May to September, whose precipitation corresponds to only $9 \%$, characterizing the dry period (MARTINS et al., 2011).

At the budding phenophase, the proportion of individuals at this phenophase was high in the rainy season, between December and January, although it was significant in the other periods. This shows that the species under study maintained the growth and production of new leaves or shoots throughout the period (Figure 2.) 


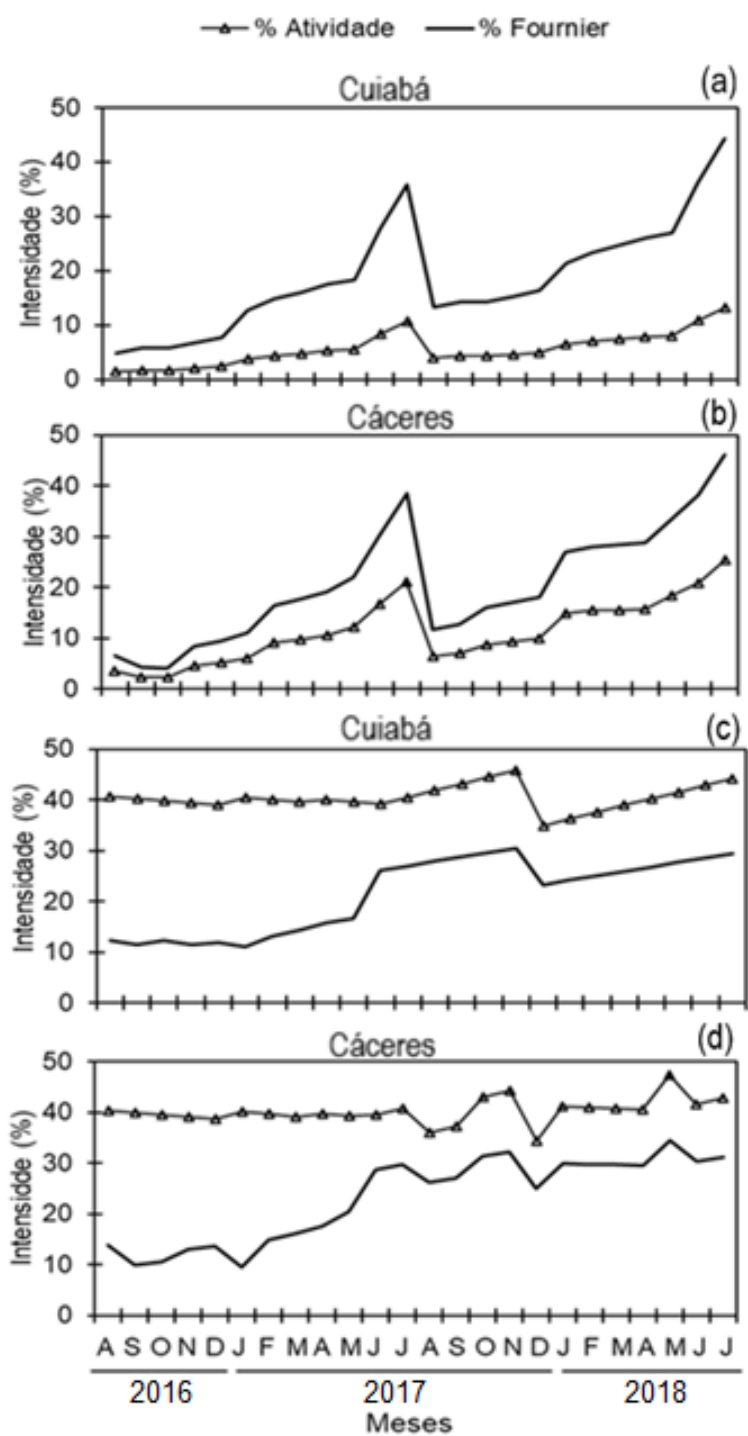

Figura 2. Índice de atividade e atividade de Fournier para fenologia vegetativa dos indivíduos de Copernicia alba nos municípios de Cuiabá e Cáceres-MT. (a, b) queda de folhas; (c, d) brotação.

Figure 2. Activity index and activity of Fournier for vegetative phenology of individuals of Copernicia alba in the municipalities of Cuiabá and Cáceres, MT. (a, b) leaf fall; (c, d) budding.

The emission flux of new leaves occurred moderately throughout the year, with a higher intensity in October (Figure 2c, d), indicating that the individuals are synchronous with this phenophase and suggesting that the budding occurs at the beginning of the year.

During the period between July and August, when individuals presented $100 \%$ of flowers with fruits, the peak of intensity for the reproductive phase reached the highest value. At the flowering phenophase (Figure 3a) and at the fruiting phenophase (Figure 3b), the activity and intensity indexes were corresponding and proportional, indicating a high intraspecific synchronicity. 


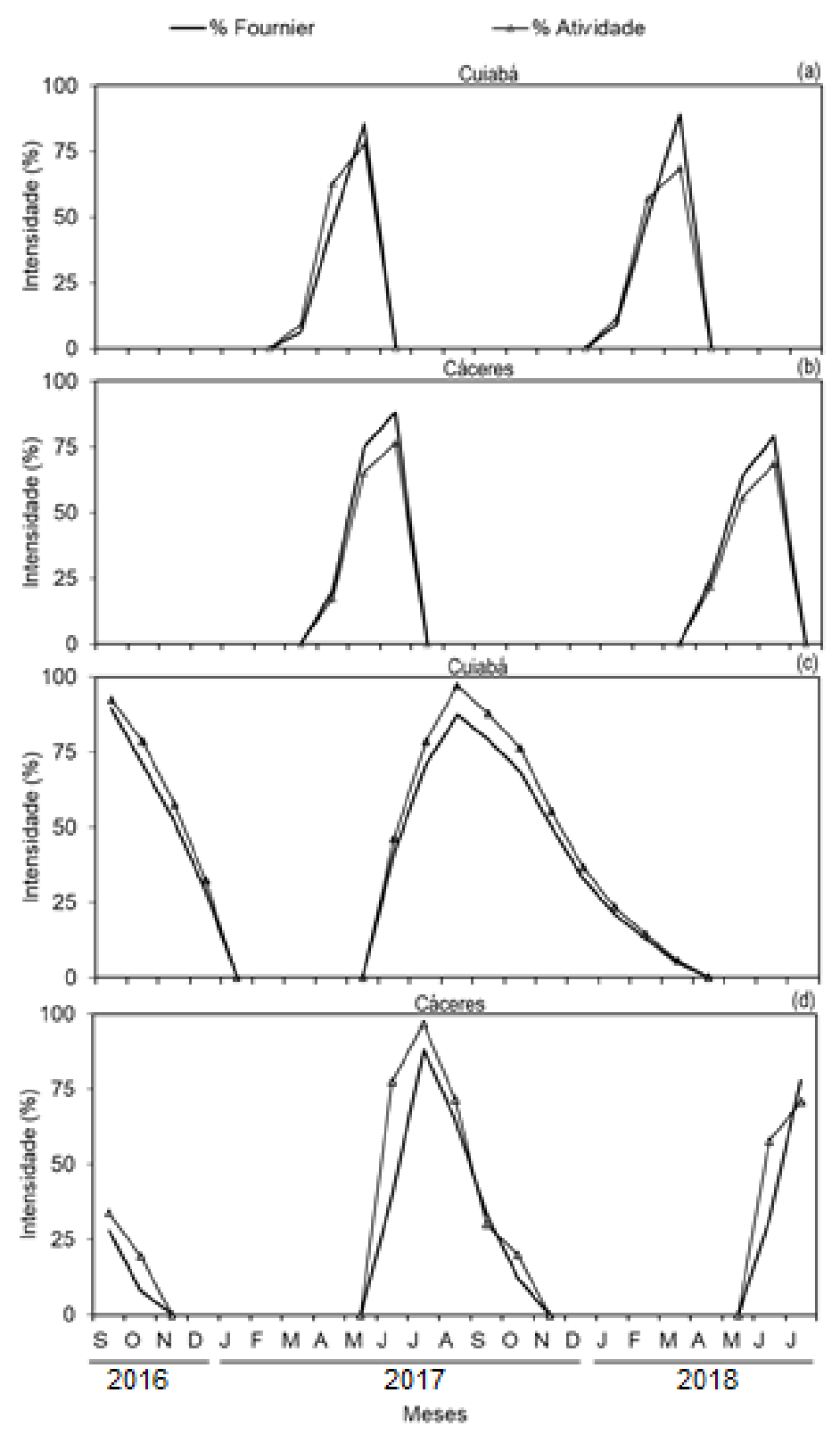

Figura 3. Fenologia de floração dos indivíduos de Copernicia alba nos municípios de Cuiabá e Cáceres-MT: (a, b) botões florais; (c, d) flores abertas.

Figure 3. Flowering phenology of individuals of Copernicia alba in the municipalities of Cuiabá and Cáceres, MT: (a, b) flower buds; (c, d) open flowers.

The fruiting of $C$. alba followed the annual flowering pattern, that is, it occurred once a year. The period of greatest intensity of unripe fruits was observed between March and April for both regions (Figure 4a, b). The intensity of the formation of ripe fruits was high, showing a peak of production in May for Cuiabá and Cáceres plants (Figure 4c, d). 


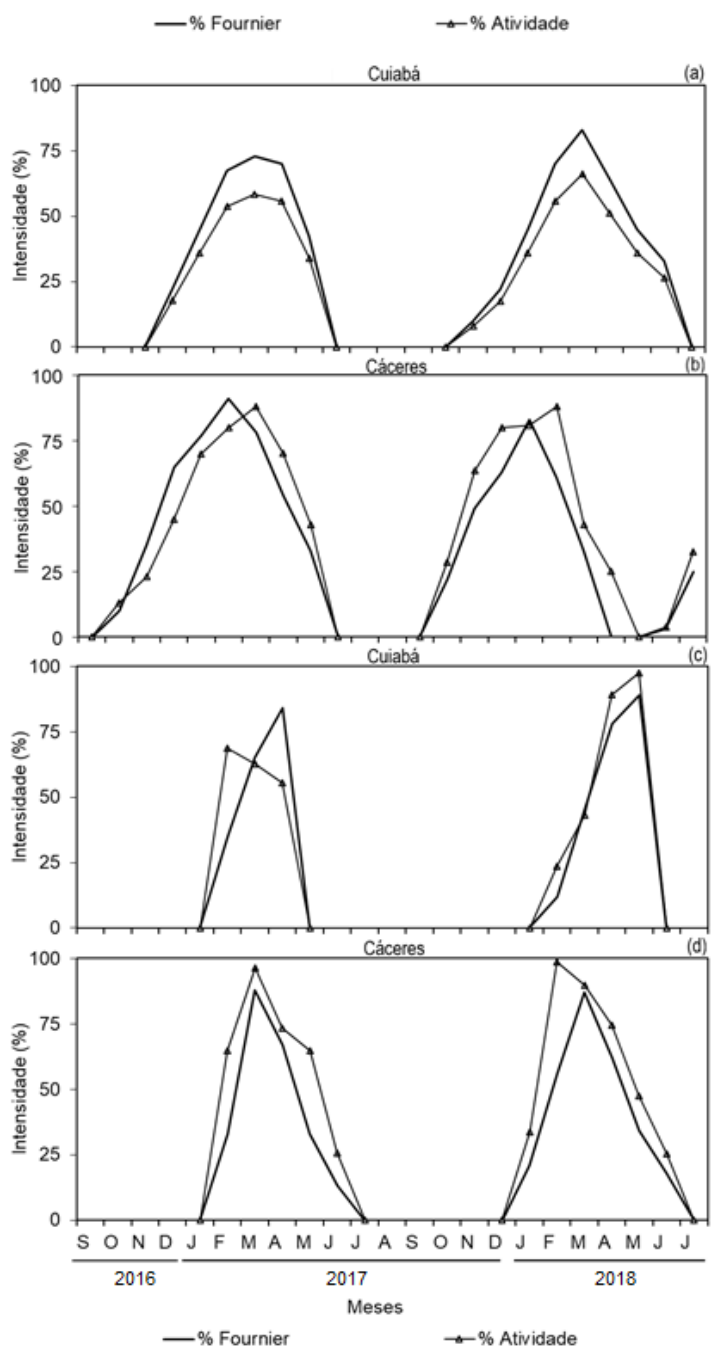

Figura 4. Fenologia de frutificação dos indivíduos de Copernicia alba nos municípios de Cuiabá e Cáceres-MT: $(a, b)$ frutos imaturos; $(c, d)$ frutos maduros.

Figure 4. Fruiting phenology of individuals of Copernicia alba in the municipalities of Cuiabá and Cáceres, MT: (a, b) unripe fruits; (c, d) ripe fruits.

Leaf loss correlated significantly with climatic variables, with the exception of wind speed, and Fournier intensity index during the four fortnights prior to the occurrence of the phenological event (Table 1).

Tabela 1. Correlações de Spearman $(\mathrm{rS})$ entre as médias quinzenais das variáveis climáticas e os eventos fenológicos vegetativos de Copernicia alba.

Table 1. Spearman correlations (rS) between biweekly averages of climatic variables and vegetative phenological events of Copernicia alba.

\begin{tabular}{|c|c|c|c|c|c|}
\hline \multirow{2}{*}{ Climate variables } & \multirow{2}{*}{ Fortnight } & \multicolumn{2}{|c|}{ Leaf loss } & \multicolumn{2}{|c|}{ Budding } \\
\hline & & Activity & Fournier & Activity & Fournier \\
\hline \multirow{4}{*}{$\mathrm{T}^{\circ} \mathrm{C}$} & $1^{\circ}$ & ns & 0.664 & ns & ns \\
\hline & $2^{\circ}$ & $\mathrm{ns}$ & 0.648 & $\mathrm{~ns}$ & ns \\
\hline & $3^{\circ}$ & ns & 0.599 & ns & -0.256 \\
\hline & $4^{\circ}$ & ns & 0.545 & ns & -0.283 \\
\hline
\end{tabular}




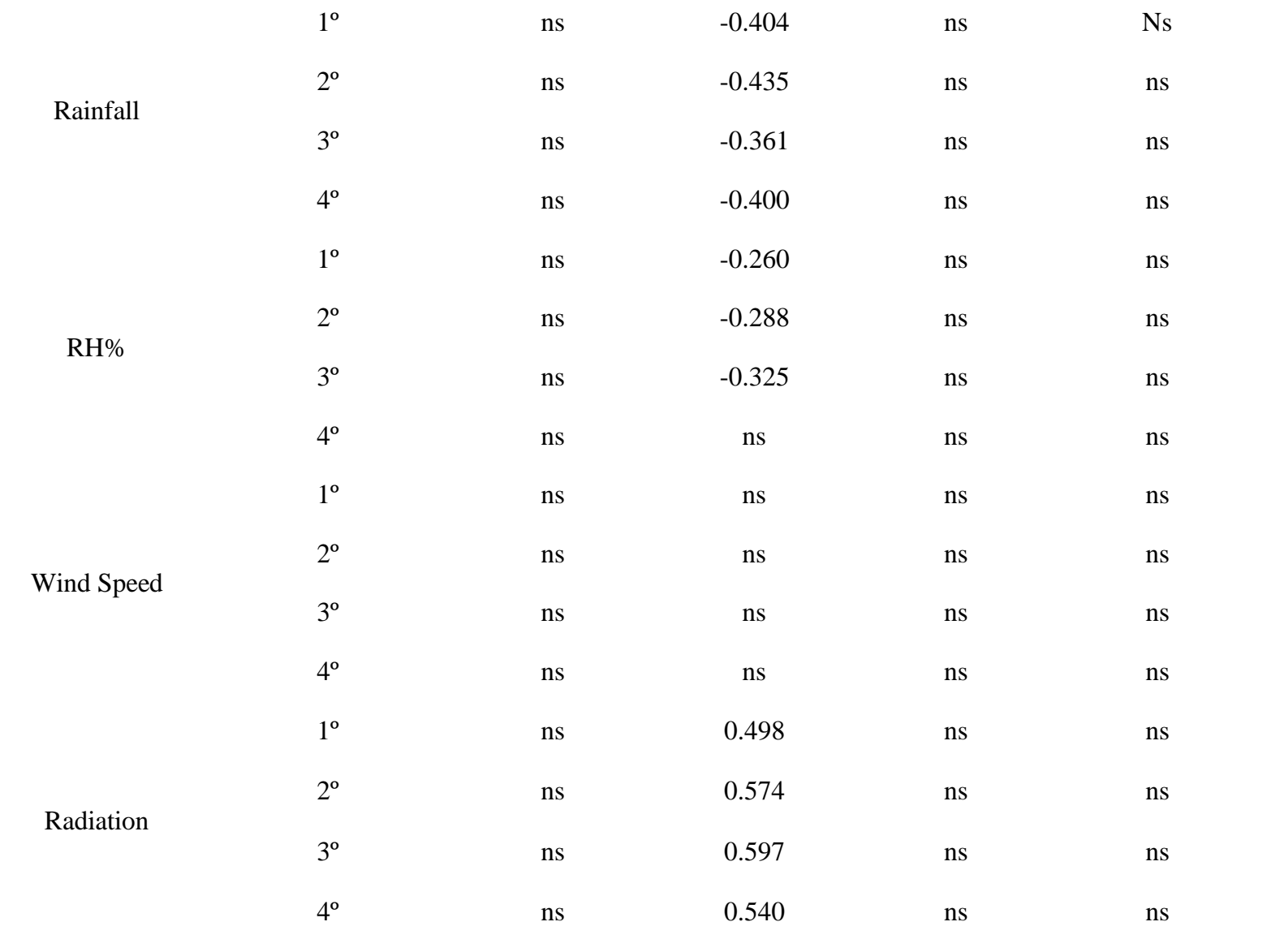

ns - not significant correlation $(\alpha=0.05) ; \mathrm{T}^{\circ} \mathrm{C}$ - average temperature; RH\% - relative humidity.

The emergence of flower buds showed a significant correlation with all climatic variables analyzed. Thus, there is a greater emission of flower buds with the increase in temperature, rainfall and relative air humidity. On the other hand, there is less emission of buds with the increase in wind speed and radiation (Table 2).

Fruiting presented a low correlation with climatic variables. The relation between unripe fruits and the period of higher temperature in the fourth week preceding the event is indicated by the positive correlation (Table 2). The decrease in wind speed in the second and third weeks prior to fruiting significantly influences the production of unripe fruits.

Tabela 2. Correlações de Spearman (rS) entre as médias quinzenais das variáveis climáticas e os eventos fenológicos reprodutivos de Copernicia alba.

Table 2. Spearman correlations (rS) between biweekly averages of climatic variables and reproductive phenological events of Copernicia alba.

\begin{tabular}{cccccccccc}
\hline \multirow{2}{*}{$\begin{array}{c}\text { Climate } \\
\text { variables }\end{array}$} & \multirow{2}{*}{ Fortnight } & \multicolumn{2}{c}{ Floral Buttons } & \multicolumn{2}{c}{ Open flowers } & \multicolumn{2}{c}{ Unripe fruits } & \multicolumn{2}{c}{ Ripe fruits } \\
\cline { 2 - 10 } & & Activ. & Fournier & Activ. & Fournier & Activ. & Fournier & Activ. & Fournier \\
\hline \multirow{2}{*}{$\mathrm{T}^{\circ} \mathrm{C}$} & $1^{\circ}$ & 0.144 & 0.160 & $\mathrm{~ns}$ & $\mathrm{~ns}$ & $\mathrm{~ns}$ & $\mathrm{~ns}$ & $\mathrm{~ns}$ & 0.611 \\
& $2^{\circ}$ & 0.156 & 0.172 & 0.444 & 0.468 & $\mathrm{~ns}$ & $\mathrm{~ns}$ & $\mathrm{~ns}$ & 0.601 \\
& $3^{\circ}$ & 0.207 & 0.223 & 0.436 & 0.46 & $\mathrm{~ns}$ & $\mathrm{~ns}$ & $\mathrm{~ns}$ & 0.566 \\
& $4^{\circ}$ & 0.256 & 0.272 & 0.488 & 0.512 & 0.388 & 0.499 & $\mathrm{~ns}$ & 0.567 \\
Rainfall & $1^{\circ}$ & 0.488 & 0.504 & $\mathrm{~ns}$ & $\mathrm{~ns}$ & $\mathrm{~ns}$ & $\mathrm{~ns}$ & $\mathrm{~ns}$ & $\mathrm{~ns}$ \\
& $2^{\circ}$ & 0.482 & 0.498 & $\mathrm{~ns}$ & 0.278 & $\mathrm{~ns}$ & $\mathrm{~ns}$ & $\mathrm{~ns}$ & $\mathrm{~ns}$ \\
\hline
\end{tabular}

FLORESTA, Curitiba, PR, v. 51, n. 1, p. 220-229, jan/mar 2021. 


\begin{tabular}{|c|c|c|c|c|c|c|c|c|c|}
\hline & $3^{\circ}$ & 0.488 & 0.504 & ns & ns & ns & ns & ns & $\mathrm{ns}$ \\
\hline \multirow{5}{*}{$\mathrm{RH} \%$} & $4^{\circ}$ & 0.501 & 0.517 & 0.187 & $\mathrm{~ns}$ & ns & ns & ns & 0.198 \\
\hline & $1^{\mathrm{o}}$ & 0.417 & 0.433 & $\mathrm{~ns}$ & $\mathrm{~ns}$ & $\mathrm{~ns}$ & $\mathrm{~ns}$ & $\mathrm{~ns}$ & 0.398 \\
\hline & $2^{\circ}$ & 0.499 & 0.515 & $\mathrm{~ns}$ & $\mathrm{~ns}$ & $\mathrm{~ns}$ & ns & ns & 0.301 \\
\hline & $3^{\circ}$ & ns & ns & $\mathrm{ns}$ & $\mathrm{ns}$ & $\mathrm{ns}$ & ns & ns & ns \\
\hline & $4^{\circ}$ & ns & ns & $\mathrm{ns}$ & ns & ns & ns & $\mathrm{ns}$ & ns \\
\hline \multirow{4}{*}{ Wind speed } & $1^{\circ}$ & -0.209 & -0.309 & $\mathrm{~ns}$ & $\mathrm{~ns}$ & ns & ns & $\mathrm{ns}$ & ns \\
\hline & $2^{\circ}$ & -0.251 & -0.351 & ns & $\mathrm{ns}$ & $\mathrm{ns}$ & 0.201 & ns & ns \\
\hline & $3^{\circ}$ & ns & ns & $\mathrm{ns}$ & ns & 0.477 & 0.469 & ns & ns \\
\hline & $4^{\circ}$ & ns & ns & $\mathrm{ns}$ & ns & ns & ns & ns & ns \\
\hline \multirow{4}{*}{ Radiation } & $1^{\mathrm{o}}$ & -0.502 & -0.414 & ns & $\mathrm{ns}$ & ns & ns & ns & ns \\
\hline & $2^{o}$ & -0.477 & -0.389 & $\mathrm{~ns}$ & $\mathrm{~ns}$ & ns & $\mathrm{ns}$ & ns & ns \\
\hline & $3^{\circ}$ & $\mathrm{ns}$ & ns & -0.333 & -0.354 & $\mathrm{~ns}$ & ns & $\mathrm{ns}$ & ns \\
\hline & $4^{\circ}$ & $\mathrm{ns}$ & $\mathrm{ns}$ & -0.387 & -0.837 & ns & ns & ns & ns \\
\hline
\end{tabular}

Activ. - intensity of activity; ns - not significant correlation $(\alpha=0.05) ; \mathrm{T}^{\circ} \mathrm{C}$ - average temperature; $\mathrm{RH} \%$ - relative humidity.

\section{DISCUSSION}

Leaf fall remained low throughout the observed period. In August and September of 2015 and 2016, there was a markedly vegetative growth of the species for both sites, and the lowest leaf fall percentage. This characterizes the vegetative development of the plant, and it can therefore be classified as perennial (NEGRELLE; DEGEN-NAUMANNN, 2012).

The dry period presented the greatest loss of leaves by the species studied, mainly in June and peaking in September. The events of senescence and leaf fall are probably related to the beginning of the dry season, when there is an increase in evapotranspiration. Thus, leaf loss in the dry season is a water saving factor for plants, and low moisture indexes stimulate leaf abscission (BAZIÉ et al., 2019).

The highest Fournier intensity indexes occurred during the period when activity indexes were higher, that is, when all the individuals of the population presented a determined phenophase with the greatest intensity. In this study, the maximum intensity reached by each individual of the population was $27 \%$ of the canopy at the phenophase.

During the rainy season, between December and March, only 5\% of the individuals presented leaf loss, while $40 \%$ of the individuals presented leaf fall during the dry season, between April and August. That is, there was a considerable variation in the number of individuals at this phenophase as they occur mainly due to the availability of water during the observed periods.

By comparing both indexes, the peaks of activity and intensity of Fournier coincided for the population of $C$. alba, indicating that there was a growth of new buds and leaves throughout the whole period. The Fournier intensity index revealed a continuous pattern of intensity for the leaf fall phenophase, indicating that there was loss of leaves during the observed period. However, there was a high intensity in the dry period. The coincidence between activity peaks and intensity tends to be more evident in vegetative phenophases, because the cumulative increase in the magnitude of these phenophases is slower and more gradual than in the reproductive phenophase (BOTREL et al., 2015).

The results obtained in this study corroborate with those obtained by Coelho e Machado (2009), who, studying the phenology of Heteropterys aphrodisiaca in different regions of Mato Grosso, observed that the leaf deciduousity appears to suffer a direct interference from the absence of rains during the dry season (between April and August). Fournier activity and intensity indexes were corresponding and proportional, indicating a high synchronization of phenophases.

FLORESTA, Curitiba, PR, v. 51, n. 1, p. 220-229, jan/mar 2021. 
The flowering of C. alba began in March with about $15 \%$ of individuals with flowers and reached the maximum flowering in September, with $90 \%$ of individuals with flowers. On the other hand, the fruiting phenophase began at the peak of flowering (September), extending until June, presenting an intense fruit production in February and an asynchronous behavior in the flowering period. Ferreira e Consolaro (2013) associated flowering in the dry season with conditions conducing to the dispersion of pollen in anemophilic species such as C. alba.

Apparently, for some Pantanal species, including C. alba, flowering seems to be associated with water availability and temperature, and this may possibly be a characteristic of the species in the region (SCREMINDIAS et al., 2011).

According to the pattern described by Piña-Rodrigues e Aguiar (1993), in anemocoric species fruit production and ripening occur in shorter periods (two to three months). In addition, fruit and seed production is abundant, usually concentrated in a particular time of the year, and fruit ripening is fast, with little variation within the same individual. The ripening, dispersal and ripening times of fruits and seeds may occur during the dry season for some species such as Tabebuia avellanedae, Schyzolobium parahybum, Copernicia cerifera, Cedrela fissilis, Cordia trichotoma, among others.

Plants may present a delayed phenological response to a given environmental stimulus (ROCHA et al., 2015). Thus, leaf fall may be related to climatic factors before the events, that is, an increase in temperature and radiation and a decrease in rainfall and relative humidity may have determined the loss of leaves.

In a study of the phenology of Copernicia prunifera in a Caatinga area of Rio Grande do Norte, Rocha et al. (2015) showed that there was also a positive correlation between the leaf fall phenophase and climatic variables. The authors attributed to the water stress, imposed to the population of plants analyzed, a determining factor to leaf abscission. The decrease in the volume of water in the most superficial layers of the soil at the beginning of the dry season has been associated with leaf fall (REBELATTO et al., 2013). Thus, the decrease in water potential may have induced leaf fall in carandá.

Flower opening showed a positive correlation with average temperature in the last three fortnights that preceded the event and with the rainfall in the last fortnight evaluated. There was a significant negative correlation with global radiation for the last two fortnights. Therefore, flower opening may be associated with later climatic conditions, indicating a high influence of temperature increase and rainfall and the decrease in global radiation in the third and/or fourth fortnight before this event.

Rocha et al. (2015) found that fruiting in C. prunifera is related to rainfall and that the influence of climate is complex, since each climatic variable seems to have a different weight in the phenology of the species. In fact, the occurrence and intensity of a particular phenophase are usually associated with one or several abiotic factors acting together, such as temperature, rainfall, moisture and nutrient availability, and biotic factors, such as pollinators, dispersants, seed predators and herbivores (NAZARENO; REIS, 2012).

\section{CONCLUSIONS}

- The carandá (Copernicia alba) is a perennial species with a great loss of leaves in the dry period, and a greater leaf intensity in the transition period between the rainy season and the dry season.

- Sprouting was observed throughout the year. However, peaks of activity and intensity of Copernicia alba, for both sites, also occurred at the end of the rainy season.

- The incidence of floral buds occurred in the dry period and an intense flowering in the transition between the dry and rainy periods. The fruiting period occurred only in the rainy season.

- Fournier activity and intensity indexes were corresponding and proportional, indicating a high intraspecific synchronization of phenophases.

\section{REFERENCES}

BAZIÉ, P.; KY-DEMBELE, C.; JOURDAN, C.; ROUPSARD, O.; ZOMBRÉ, G.; BAYALA, J. Synchrony in the phenologies of fine roots and leaves of Vitellaria paradoxa in different land uses of Burkina Faso. Agroforest Syst, Springer Netherlands, v. 93, n. 2. p. $449-460,2019$.

BELO, R. M.; NEGREIROS, D.; FERNANDES, G. W.; SILVEIRA, F. A. O.; RANIERI, B. D.; MORELLATO, P. C. Fenologia reprodutiva e vegetativa de arbustos endêmicos de campo rupestre na Serra do Cipó, Sudeste do Brasil. Rodriguesia, Rio de Janeiro, n. 64, v. 4, p. 817-828, 2013.

BOTREL, R. T.; BRITO, D. R. S.; SOUSA, W. C.; SOUZA, A. M.; HOLANDA, A. C. Fenologia de uma espécie arbórea em ecótono Caatinga / Cerrado no sul do Piauí. Revista Verde, Pombal, v. 10, n.3, p. 07 - 12, 2015

CHUINE, I. Why does phenology drive species distribution? Philosophical Transactions B, Londres, v. 365, n. 1555,

FLORESTA, Curitiba, PR, v. 51, n. 1, p. 220-229, jan/mar 2021. 
p. $3149-3160,2010$.

COELHO, A.; SPILLER, C. Fenologia de Heteropterys aphrodisiaca O. Mach. - Malpighiaceae, em Mato Grosso. Revista Brasileira de Plantas Medicinais, Botucatu, v. 10, n. 1, p. 1 - 7, 2008.

CONCEIÇÃO, A.A.; FUNCH, L.S.; PIRANI, J. R. Reproductive phenology, pollination and seed dispersal syndromes on sandstone outcrop vegetation in the "Chapada Diamantina", northeastern Brazil: population and community analyses. Revista Brasileira de Botânica, São Paulo, v. 30, n. 3, p. 475 - 485, 2007.

DUTRA, V.F.; VIEIRA, M. F.; GARCIA, F. C. P.; LIMA, H. C. Fenologia reprodutiva, síndromes de polinização e dispersão de Leguminosas. Rodriguesia, Rio de Janeiro, v. 60, n. 2, p. 371 - 387, 2009.

FAVA, C. L. F.; ALBUQUERQUE, M. C. F. Emergência de plântulas de Copernicia alba (Morong ex Morong e Britton) em função da escari cação mecânica e imersão de sementes. Revista Brasileira de Horticultura Ornamental, Campinas, v. 17, n. 2, p. 127 - 132, 2011.

FERREIRA, M. C.; CONSOLARO, H. Fenologia e síndromes de polinização e dispersão de espécies de sub-bosque em um remanescente florestal urbano no brasil central. Bioscience Journal, Uberlândia, v. 29, n. 1, p. 1708 - $1720,2013$.

FOURNIER, L. A. Un método cuantitativo para la medición de características fenológicas en árboles. Turrialba, São José, v. 24, n. 4, p. 422 - 423, 1974.

INMET - Instituto Nacional de Meteorologia (INMET) Disponível em: http://www.inmet.gov.br/portal/.

KOPTUR, S.; HABER, W. A.; FRANKIE, G. W.; BAKER, H. G. Phenological studies of shrub and treelet species in tropical cloud forests of Costa Rica. Journal of Tropical Ecology, Cambridge, v. 4, n. 4, p. 323 - 346, 1988.

MARCHIORETTO, M. S.; MAUHS, J.; BUDKE, J. C. Fenologia de espécies arbóreas zoocóricas em uma floresta psamófila no sul do Brasil. Acta Botanica Brasilica, Belo Horizonge, v. 21, n. 1, p. 193-201, 2007.

MARTINS, J.A.; DALLACORT, R.; INOUE, M. H.; GALVANIN, E. A. S.; MAGNANI, E. B. Z.; OLIVEIRA, K. C. Caracterização do regime pluviométrico no arco das nascentes do rio Paraguai. Revista Brasileira de Meteorologia, São José dos Campos, v. 26, n. 4, p. 639 - 647, 2011.

MIOLA, D. T. B.; FREITAS, C. R.; BARBOSA, M.; FERNANDES, G. W. Modeling the spatial distribution of the endemic and threatened palm shrub Syagrus glaucescens (Arecaceae). Neotropical Biology and Conservation, São Leopoldo, v. 6, n. 2, p. 78-84, 2011.

MORELlATO, L. P. C.; LEITÃO-FILHO, H. F. História natural da Serra do Japi: ecologia e preservação de uma área florestal no Sudeste do Brasil, Campinas: Ed.UNICAMP; 1992, 321 p.

NAZARENO, A. G.; REIS, M. S. Linking phenology to mating system: exploring the reproductive biology of the threatened palm species Butia eriospatha. Journal of Heredity, Oxford, v. 103, n. 1, p. 842 - 852, 2012.

NEGRElle, R. R. B.; DEGEN-NAUMANNN, R. L. Copernicia alba Morong ex Morong \& Britton: Aspectos botânicos, ecológicos, etnobotânicos e agronômicos. Visão Acadêmica, Curitiba, v. 13, n. 2, p. 60 - 71, 2012.

NEWSTROM, L. E.; FRANKIE, G. W.; BAKER, H. G. A New Classification for Plant Phenology Based on Flowering Patterns in Lowland Tropical Rain Forest Trees at La Selva. Biotropica, Flórida,v. 26, n. 1, p. 141 - $148,1994$.

Piña-Rodrigues FCM, AGUIAR IB. Maturação e dispersão de sementes. In: AGUIAR IB, PiñaRodrigues FCM, Figliolia MB.(Eds.). Sementes florestais tropicais. Brasília: ABRATES: 1993, 350 p.

SCREMIN-DIAS, E. I.; LORENZ-LEMKE, A. P. I.; OLIVEIRA, A. K. M. The floristic heterogeneity of the Pantanal and the occurrence of species with different adaptive strategies to water stress. Brazilian Journal of Biology, São Carlos, v. 71, n. 1, p. 275 - 282, 2011.

SOUZA, D. N. N.; CAMACHO, R. G. V.; MELO, J. I. M.; ROCHA, L. N. G.; SILVA, N. F.. Estudo fenológico de espécies arbóreas nativas em uma unidade de conservação de caatinga no Estado do Rio Grande do Norte, Brasil. Biotemas, Florianópolis, v. 27, n. 2. p. 31 - 42, 2014.

REBELATTO, D.; LEAL, T. S.; MORAES, C. P. Fenologia de duas espécies de ipê em área urbana do município de Araras, São Paulo, Brasil. Revista da Soc. Brasileira de Arborização Urbana, Piracicaba, v. 1, n. 8, p. 1 - $16,2013$.

ROCHA, T. G.; SILVA, R. A. R.; DANTAS, E. X.; VIEIRA, F. A. Fenologia da Copernicia prunifera (arecaceae) em uma área de caatinga do Rio Grande do Norte. Cerne, Lavras, v. 2, n. 4, p. 673 - 682, 2015.

VALENTINI, C. M. A.; DE ALMEIDA, J. D.; COELHO, M. F. B.; RODRÍGUEZ-ORTÍZ, C. E. Fenologia da Siparuna guianensis Aublet em dois bosques de preservaçãoo ambiental em Cuiabá-MT. Cerne, Lavras, v. 19, n. 4, p. 581 - 591 , 2013.

FLORESTA, Curitiba, PR, v. 51, n. 1, p. 220-229, jan/mar 2021. 